Tropical Journal of Pharmaceutical Research January 2020; 19 (1): 45-49

ISSN: $1596-5996$ (print); 1596-9827 (electronic)

(C) Pharmacotherapy Group, Faculty of Pharmacy, University of Benin, Benin City, 300001 Nigeria.

\title{
Determination of radical scavenging activities of some pyrimidine derivatives
}

\author{
Oluwole S Aremu ${ }^{1 *}$, Lebogang Katata-Seru${ }^{1}$, Olukayode O Aremu ${ }^{2}$, Constance \\ R Sewani-Rusike ${ }^{2}$, Neil Koorbanally ${ }^{3}$ \\ ${ }^{1}$ Department of Chemistry, Faculty of Natural and Agriculture Science, North West University, Mafikeng campus, Private bag \\ X2046, Mmabatho 2745, ${ }^{2}$ Department of Human Biology, Faculty of Health Sciences, Walter Sisulu University, Mthatha 5117, \\ South Africa; ${ }^{3}$ School of Chemistry and Physics, Westville campus, University of KwaZulu-Natal, Durban 4000,
}

*For correspondence: Email: 23859539@nwu.ac.za; Tel: +27-842905180

Sent for review: 15 February 2018

Revised accepted: 16 October 2019

\begin{abstract}
Purpose: To synthesize some pyrimidine derivatives and investigate their radical scavenging activities. Methods: A series of newly pyranopyrimidines derivatives and dithiopyridopyrimidinediones were synthesized by condensation of barbituric acid, malononitrile and different substituted benzaldehydes reacted with 1,4-Diazabicyclo[2.2.2] octane (DABCO) as a base. Compounds P1-7 (series 1), S1-11 (series 2) Scheme 1 and 6-amino-2-thiouracil with aromatic aldehydes in glacial acetic acid under reflux J1-13 (series 3) Scheme 2. ${ }^{1} \mathrm{H} \&{ }^{13} \mathrm{C}$ NMR, CHN, GC-MS and IR were used to characterize the compounds and were also screened for radical scavenging activity using 2,2-diphenyl-1-picrylhydrazyl (DPPH) radical scavenging activity $\left(I C_{50}=50 \mu \mathrm{g} / \mathrm{ml}\right)$.

Results: The potency of radical scavenging activity was ranked as series $1>$ series $3>$ series 2 . Compounds P3, J4, S10, P5, P7 with inhibitory concentration at $50 \%$ level $\left(I C_{50}\right)$ of $12,40,48,50$, and $54 \mu \mathrm{g} / \mathrm{ml}$, respectively, showed radical scavenging activity equal or more potent than the standard antioxidant, ascorbic acid $\left(I C_{50}=50 \mu \mathrm{g} / \mathrm{ml}\right)$.

Conclusion: Series of newly pyranopyrimidines and dithiopyridopyrimidinediones derivatives have been successfully synthesized, and they demonstrate good radical scavenging activity.
\end{abstract}

Keywords: Pyranopyrimidine, Dipyrimidines, Anti-oxidant, DPPH, Ascorbic acid, Radical scavenging

\begin{abstract}
This is an Open Access article that uses a fund-ing model which does not charge readers or their institutions for access and distributed under the terms of the Creative Commons Attribution License (http://creativecommons.org/licenses/by/4.0) and the Budapest Open Access Initiative (http://www.budapestopenaccessinitiative.org/read), which permit unrestricted use, distribution, and reproduction in any medium, provided the original work is properly credited.
\end{abstract}

Tropical Journal of Pharmaceutical Research is indexed by Science Citation Index (SciSearch), Scopus, International Pharmaceutical Abstract, Chemical Abstracts, Embase, Index Copernicus, EBSCO, African Index Medicus, JournalSeek, Journal Citation Reports/Science Edition, Directory of Open Access Journals (DOAJ), African Journal Online, Bioline International, Open-J-Gate and Pharmacy Abstracts

\section{INTRODUCTION}

Pyrimidine is a six-membered heterocyclic aromatic organic compound that contains two nitrogen atoms at positions 1 and 3 . It is known to possess some pharmacological activities, such as antiviral, anticancer [1-3], antimicrobial [4-6], anti-inflammatory [7] and antimalarial [8,9]. Molecules containing a pyrimidines scaffold is known to have pharmacological properties [10]. Some heterocyclic derivatives of pyrimidines such as pyranopyrimidines and dithiopyridopyrimidinediones derivatives contain pyrimidine, pyrano, pyrido and aryl moieties [11].

The pyranopyrimidines and dithiopyridopyrimidinediones derivatives have been previously 
synthesized by various methods as previously reported. [12].

Reactive oxygen species (ROS), such as superoxide radical anions, hydrogen peroxide and hydroxyl radical are free radicals continuously produced during normal metabolic pathways and in pathology [13]. Excessive production of ROS is deleterious to cellular proteins and lipids due to oxidative damage. The body's endogenous antioxidant system acts as a ROS scavenger to protect cells and macromolecules from oxidative damage. Disturbances of anti-oxidant status are seen in diabetes, hypertension, obesity, infertility, Alzheimer's disease, Parkinson's disease and cancer [14]. As such, supplementing the endogenous antioxidant system is being investigated as a possible therapy in prevention, as well as limiting progression and development of complications, of chronic diseases. In view of this, we report on the investigation of the antioxidant properties of the synthesized pyrimidine compounds using 1, 1-diphenyl-2picrylhydrazyl (DPPH) and free radical scavenging assay.

\section{EXPERIMENTAL}

\section{Materials}

All chemicals and solvents used in this study are of analytical grade and were purchased from Sigma Aldrich via Capital Laboratories, South Africa. All organic solvents were redistilled and dried according to standard procedures. Nuclear magnetic resonance (NMR) spectra were recorded using Bruker Avance III $400 \mathrm{MHz}$ spectrometer at room temperature, with chemical shifts $(\delta)$ recorded against the internal standard, tetramethylsilane (TMS). IR spectra were recorded on a Perkin Elmer Spectrum 100 ATRFTIR spectrometer. For GC-MS analyses, the samples were analyzed on an Agilent GC-MSD apparatus equipped with DB-5SIL MS $(30 \mathrm{~m}$ $\times 0.25 \mathrm{~mm}$ i.d., $0.25 \mu \mathrm{m}$ film thickness) fusedsilica capillary column. Helium (at $2 \mathrm{~mL}$ min-1) was used as a carrier gas. MS was operated in Elmode at $70 \mathrm{eV}$. Optical rotation was recorded using a polarimeter (Model 341, Perkin Elmer Inc, USA). Melting points were recorded on an Ernst Leitz Wetzlar microhot stage melting point apparatus.

\section{General procedure for the synthesis of pyranopyrimidione derivatives (P1-7, S1-11)}

Reported procedure [12]. was used in synthesizing this library of compounds by reacting barbituric acid, benzaldehyde derivatives (ArCHO), malononitrile $(1.0 \mathrm{mmol}$ each) and $10 \%$ DABCO in a clean $50 \mathrm{ml}$ round bottom flask containing $20 \mathrm{ml}$ of aqueous ethanol (Scheme 1). The reaction mixture was stirred for a period of 60 minutes. The progress of the reaction was monitored by TLC. For most of this synthesis, the products were filtered, recrystallized in ethanol and dried under vacuum pressure, with good yields of the final products.

\section{General procedure for the synthesis of dithiopyridopyrimidinediones) derivatives (J1-13)}

A solution of 6 -amino-2-thiouracil $4(3 \mathrm{mmol})$ in glacial acetic acid $(15 \mathrm{ml})$ and 0.5 equiv. of the appropriate aromatic aldehyde was heated under reflux for 4 hours. The reaction mixture was diluted with water and then allowed to cool to room temperature. The crude product was collected and recrystallized from a suitable solvent. Details have been reported in previously published articles from our group [15].

\section{Evaluation of antioxidant properties}

The free radical scavenging activity of the synthesized compounds was determined by 1,1 diphenyl-2- picrylhydrazyl (DPPH) method, as described by Brand William et al (1995) [16]. In this protocol, DPPH $\bullet$ acts as a stable free radical with a purple colour. In the presence of an antioxidant that donates an electron, the purple colour of DPPH - decays. This change can be monitored spectrophotometrically and used to assess radical scavenging activity, which equates to antioxidant activity of compounds. For this study, compounds were dissolved in a minimum volume of DMSO and diluted in ethanol to $1 \mathrm{mg} / \mathrm{ml}$. To $1 \mathrm{ml}$ of compound or ascorbic acid, the standard $(500,250,125$ and $62.5 \mu \mathrm{g} / \mathrm{ml})$ in a test tube, $3 \mathrm{ml}$ of $0.5 \mathrm{mM}$ ethanolic solution of DPPH was added. The mixture was vortexed vigorously and incubated for 30 minutes in the dark at room temperature. Absorbance was read spectrophotometrically at $517 \mathrm{~nm}$ and inhibition of DPPH free-radical scavenging activity (D) was computed as in Eq 1.

$\mathrm{D}\{(\mathrm{Ac} \mathrm{As}) / \mathrm{Ac}\} 100$

where Ac and As are the absorbance of control and test sample, respectively.

\section{RESULTS}

\section{Chemistry}

Various pyranopyrimidiones derivatives $\mathrm{P} 1-7$ and S1-11) (Scheme 1) have been reported in the 
literature [12]. Scheme 1 showed the good yields of the synthesized final products, whereas, Scheme 2 revealed dithiopyridopyrimidines derivatives (J1-13) synthesized, as reported in the literature [15]. Hence, the formation of the title compounds was confirmed and further established by ${ }^{13} \mathrm{C}$ NMR and mass spectroscopic studies, which agree with the molecular formula.

\section{Antioxidant activity}

Radical scavenging activity of compounds is shown in Tables 1 to 4 . Better radical scavenging activity was observed for series 1 than for series 2 compounds, with three (27\%) showing no activity at the lowest concentration of $62.5 \mu \mathrm{g} / \mathrm{ml}$, contrary to series 2 that showed three $(27 \%)$ with no activity at all and five (45\%) showing no activity at the lowest concentration of $62.5 \mu \mathrm{g} / \mathrm{ml}$. Although series 3 compounds showed radical scavenging activity at all concentrations, the $\mathrm{IC}_{50}$ values were very high compared to that in series 1. Thus, potency in radical scavenging activity is ranked as series $1>$ series $3>$ series 2 (Table 1). Overall, when compared to ascorbic acid $\left(\mathrm{IC}_{50}\right.$
$=50 \mu \mathrm{g} / \mathrm{ml})$, a known and potent antioxidant compound, five compounds have equal or better radical scavenging activity: $3, \mathrm{C} 4, \mathrm{~B} 10,5,7$ with $I_{50}$ of $12,40,48,50$, and $54 \mu \mathrm{g} / \mathrm{ml}$ respectively (Table 2 and Figure 1).

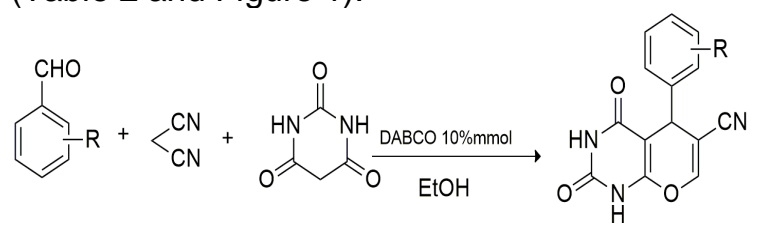

Scheme 1: Synthesis of pyranopyrimidiones (P1-7, S1-12) (oxygenated and halogenated compounds)

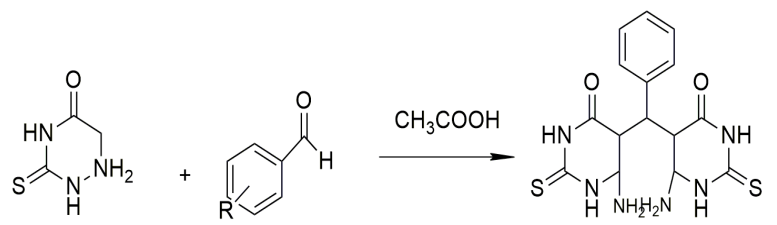

Scheme 2: Synthesis of dithiopyridopyrimidiones derivatives (J1-13)

Table 1: Radical scavenging activity of synthesized compounds

\begin{tabular}{|c|c|c|c|c|c|}
\hline \multirow[t]{2}{*}{ Compound } & \multicolumn{5}{|c|}{ DPPH inhibition (\%) } \\
\hline & $500 \mu \mathrm{g} / \mathrm{ml}$ & $250 \mu \mathrm{g} / \mathrm{ml}$ & $125 \mu \mathrm{g} / \mathrm{ml}$ & $62.5 \mu \mathrm{g} / \mathrm{ml}$ & $I C_{50}(\mu \mathrm{g} / \mathrm{m} I)$ \\
\hline $\mathrm{P} 1$ & 42 & 28 & 18 & 11 & 595 \\
\hline P2 & 66 & 52 & 32 & 17 & 240 \\
\hline P3 & 79 & 79 & 78 & 78 & 12 \\
\hline P4 & 47 & 31 & 17 & & 532 \\
\hline P5 & 78 & 77 & 73 & 62 & 50 \\
\hline P6 & 87 & 54 & 26 & 17 & 230 \\
\hline P7 & 81 & 82 & 77 & 57 & 54 \\
\hline S1 & 60 & 45 & 28 & 16 & 225 \\
\hline S2 & 42 & 25 & 18 & - & 595 \\
\hline S3 & 28 & 19 & 12 & - & 893 \\
\hline S4 & 50 & 32 & 17 & - & 500 \\
\hline S5 & - & - & - & - & 1000 \\
\hline S6 & 45 & 26 & - & - & 555 \\
\hline S7 & & & - & - & 1000 \\
\hline S8 & & - & - & - & 1000 \\
\hline S9 & 25 & 11 & - & - & 893 \\
\hline $\mathrm{S} 10$ & 28 & 28 & 28 & 18 & 900 \\
\hline $\mathrm{S} 11$ & 88 & 88 & 77 & 65 & 48 \\
\hline $\mathrm{J} 1$ & 87 & 65 & 47 & 33 & 133 \\
\hline $\mathrm{J} 2$ & 91 & 89 & 69 & 51 & 61 \\
\hline J3 & 57 & 44 & 34 & 29 & 440 \\
\hline J4 & 91 & 91 & 89 & 78 & 40 \\
\hline J5 & 65 & 50 & 35 & 28 & 250 \\
\hline J6 & 82 & 69 & 46 & 39 & 136 \\
\hline J7 & 54 & 38 & 31 & 26 & 460 \\
\hline J8 & 59 & 46 & 32 & 25 & 420 \\
\hline J9 & 52 & 44 & 34 & 27 & 480 \\
\hline J10 & 63 & 46 & 33 & 24 & 270 \\
\hline J11 & 50 & 40 & 35 & 27 & 500 \\
\hline J12 & 52 & 39 & 30 & 23 & 480 \\
\hline JP13 & 64 & 44 & 33 & 21 & 280 \\
\hline Ascorbic acid & 96 & 96 & 92 & 65 & 50 \\
\hline
\end{tabular}


Table 2: All compounds DPPH inhibition activity ranked (highest to lowest) comparing with AA

\begin{tabular}{|c|c|c|c|c|c|}
\hline \multirow{2}{*}{ Compound } & \multicolumn{5}{|c|}{ DPPH inhibition (\%) } \\
\hline & $500 \mu \mathrm{g} / \mathrm{ml}$ & $250 \mu \mathrm{g} / \mathrm{ml}$ & $125 \mu \mathrm{g} / \mathrm{ml}$ & $62.5 \mu \mathrm{g} / \mathrm{ml}$ & IC50 ( $\mathrm{\mu g} / \mathrm{mI})$ \\
\hline P3 & 79 & 79 & 78 & 78 & 12 \\
\hline J4 & 91 & 91 & 89 & 78 & 40 \\
\hline S10 & 88 & 88 & 77 & 65 & 48 \\
\hline P5 & 78 & 77 & 73 & 62 & 50 \\
\hline Ascorbic acid & 96 & 96 & 92 & 65 & 50 \\
\hline P7 & 81 & 82 & 77 & 57 & 54 \\
\hline J2 & 91 & 89 & 69 & 51 & 61 \\
\hline J1 & 87 & 65 & 47 & 33 & 133 \\
\hline J6 & 82 & 69 & 46 & 39 & 136 \\
\hline S1 & 60 & 45 & 28 & 16 & 225 \\
\hline P4 & 57 & 54 & 38 & 11 & 230 \\
\hline $\mathrm{P} 2$ & 66 & 52 & 32 & 17 & 240 \\
\hline J5 & 65 & 50 & 35 & 28 & 250 \\
\hline J8 & 68 & 50 & 41 & 33 & 250 \\
\hline J4 & 56 & 41 & 28 & 17 & 446 \\
\hline J10 & 53 & 44 & 35 & 26 & 472 \\
\hline S4 & 50 & 32 & 17 & - & 500 \\
\hline $\mathrm{J} 11$ & 50 & 40 & 35 & 27 & 500 \\
\hline B7 & 45 & 26 & - & - & 555 \\
\hline P1 & 42 & 28 & 18 & 11 & 595 \\
\hline S2 & 42 & 25 & 18 & - & 595 \\
\hline J9 & 42 & 39 & 30 & 27 & 595 \\
\hline P6 & 41 & 22 & 12 & - & 610 \\
\hline S3 & 28 & 19 & 12 & - & 893 \\
\hline S9 & 25 & 11 & - & - & 893 \\
\hline S5 & - & - & - & - & 1000 \\
\hline S7 & - & - & - & - & 1000 \\
\hline S8 & - & - & - & - & 1000 \\
\hline
\end{tabular}

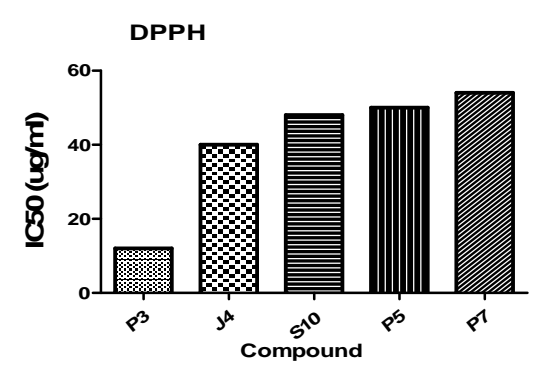

Figure 1: Potential inhibition capacities of the most potent synthesized compounds (rank order: P3 > J4> $\mathrm{S} 10>\mathrm{P} 5>\mathrm{P} 7$ )

\section{DISCUSSION}

A series of new pyranopyrimidiones and dithiopyridopyrimidiones derivatives were synthesized and evaluated for radical scavenging activity.

Pyrimidines, also known as the breakdown products of uric acid, play a vital role in the medicinal chemistry, due to their structures and composition, and act as the key templates associated with the development of different therapeutic agents $[16,20]$. Several literatures have reported on antioxidant activities of some pyrimidine derivatives $[17,18]$. In the present study, five compounds have equal or better radical scavenging activity when compared to ascorbic acid $\left(\mathrm{IC}_{50}=50 \mu \mathrm{g} / \mathrm{ml}\right)$, a known and potent antioxidant compound. This may be due to the available $\mathrm{NH}$ and $\mathrm{SH}$ group present in the synthesized pyrimidines [19].

\section{CONCLUSION}

A series of pyranopyrimidiones and dithiopyridopyrimidiones derivatives have successfully been synthesized and they exhibit radical scavenging activity in the rank order of series $1>$ series $3>$ series 2 .

\section{DECLARATIONS}

\section{Acknowledgement}

The authors acknowledge the School of Chemistry and Physics, University of KwaZuluNatal, the Department of Chemistry at North West University, Mafikeng Campus, and Walter Sisulu University Research Department for financial support during this work.

\section{Conflict of interest}

No conflict of interest is associated with this work. 


\section{Contribution of authors}

We declare that this work was done by the author(s) mentioned in this article and all liabilities pertaining to claims relating to the content of this article will be borne by the authors. Oluwole S. Aremu and Neil Koorbanally devised and designed the study, Oluwole S. Aremu carried out the laboratory work on the chemistry aspect, Olukayode O. Aremu and Constance R. Sewani-Rusike investigated the antioxidant properties of the synthesized pyrimidines, Lebogang Katata-Seru edited the raw data. The manuscript was proof-read by all the authors and approved for publication.

\section{Open Access}

This is an Open Access article that uses a funding model which does not charge readers or their institutions for access and distributed under the terms of the Creative Commons Attribution License (http://creativecommons.org/licenses/by/ 4.0) and the Budapest Open Access Initiative (http://www.budapestopenaccessinitiative.org/rea d), which permit unrestricted use, distribution, and reproduction in any medium, provided the original work is properly credited.

\section{REFERENCES}

1. Okesli A, Khosla C, Bassik MC. Human pyrimidine nucleotide biosynthesis as a target for antiviral chemotherapy. Curr. Opin. Biotechnol. 2017; 48: 127134.

2. Mohan SB, Ravi Kumar BV, Dinda SC, Naik D, Prabhu Seenivasan S, Kumar V, Rana DN, Brahmkshatriya PS. Microwave assisted synthesis, molecular docking and antitubercular activity of 1, 2, 3, 4-tethydro-pyrimidin-5carbonitrile derivatives. Bioorg. Med. Chem. Lett. 2010; 22(24): 7539-7542.

3. El-Gazzar AR, Hussein HA, Hafez HN. Synthesis and biological evaluation of thieno [2, 3-d] pyrimidine derivatives for anti-inflammatory, analgesic and ulcerogenic activity. Acta Pharm 2007; 57(4): 395-411.

4. Sherif AF, Hayam MA, Heba A. Synthesis and biological evaluation of some novel polysubstituted pyrimidine derivatives as potential antimicrobial and anticancer agents. Arch. Pharm. 2009; 342(5): 299-310.

5. Hilmy KM, Khalifa MM, Hawata MA, Keshk RM, elTorgman AA. Synthesis of new pyrrole [2,3-d] pyrimidine derivatives as antibacterial and antifungal agents. Eur. J. Med. Chem. 2010; 45(11): 5243-5250.

6. Verbitskiy EV, Baskakova SA, Kungurov NV, Kravchenko MA, Skornyakov SN, Pervova MG, Rusinov GL, Chupakhin ON, Charushin VN. Synthesis and biological evaluation of novel 5-aryl-4-(5-nitrofuran-2-yl)- pyrimidines as potential anti-bacterial agents. Bioorg. Med. Chem. Lett 2017; 27(13): 3003-3006.

7. Nofal ZM, Fahmy HH, Zarea ES, El-Eraky W. Synthesis of new pyrimidine derivatives with evaluation of their anti-inflammatory and analgesic activities. Acta. Pol. Pharm. 2009; 68(4): 507-517.

8. Azeredo LFS, Coutinho JP, Jabor VA, Feliciano PR, Nonato MC, Kaiser CR, Menezes CMS, Hammes AS, Caffarena ER, Hoelz LV. Evaluation of 7arylaminopyrazolo [1, 5-a] pyrimidines as antiPlasmodium falciparum, antimalarial, and Pfdihydroorotate dehydrogenase inhibitors. Eur. J. Med. Chem. 2017; 126: 72-83.

9. Sun L, Jie W, Zhang L, Luo M, Sun D. Synthesis and antifungal activities of some novel pyrimidine derivatives. Molecules 2011; 16: 5618-5628.

10. Mohamed MS, Awad SM, Sayed Al. Synthesis of certain pyrimidine derivatives as antimicrobial agents and antiinflammatory agents. Molecules 2010; 15(3): 18821890.

11. Mohana KN, Kumar BNP, Mallesha L. Synthesis and biological activity of some pyrimidine derivatives, Drug Invent Today. 2013; 5: 216 -22.

12. Oluwole S Aremu, Gopaul K, Kadam P, Singh M, Mocktar C, Singh PA, Koorbanally N. Synthesis, Characterization, Anticancer and Antibacterial Activity of Some Novel Pyrano [2, 3-d] pyrimidinone Carbonitrile Derivatives. Anticancer Agents Med. Chem. 2017, 17 (5), 719-725.

13. Castro L, Freeman BA. Reactive oxygen species in human health and disease. Nutr. J. 2001; 17(2), 161165.

14. Halliwell B. Free radicals, antioxidants, and human disease: curiosity, cause, or consequence? Lancet 1994; 344: 721-724.

15. Aremu OS, Singh $M$, Singh $P$, Koorbanally NA. Facile one-pot synthesis of novel Pyridodipyrimidine derivatives: Their Anticancer activity against HeLa human cervical cancer cell line. Bioorg. Chem Let 2015 (In press).

16. Brand-Williams W, Cuvelier ME, Berset $C$ and Lebensm. $W$. Use of a free radical method to evaluate antioxidant activity. Technol. 1995; 28: 25-32

17. Himaja $M$, Rout $P K$, Karigar AA, Poppy $D$, Munirajashekhar $D$. Synthesis and antioxidant activity of 4,6 - diphenylpyrimidine- 2- amine \& its derivatives. Univ J Pharm 2012; 01(01): 72-77.

18. Bano $T$, Kumar $N$, Dudhe $R$. Free radical scavenging properties of pyrimidine derivatives. Org Med Chem Lett 2012; 2(1): 34.

19. Dansena H, Dhongade HJ, Chandrakar $K$. Pharmacological Potentials of Pyrimidine Derivative: A Review. Asian J Pharm Clin Res 2015; 8(4): 171-177.

20. Ghomi AS, Ali M. An efficient route to the synthesis of pyrimidine2-ones under ultrasound irradiation. Dig $J$ Nanomater Biostruct 2010; 5(2): 303-306. 